\title{
BLENDED LEARNING IN FRENCH INTERMEDIATE GRAMMAR LEARNING: IS IT EFFECTIVE?
}

\author{
Roswita Lumban Tobing*, Dwiyanto Djoko Pranowo \\ Universitas Negeri Yogyakarta, Indonesia \\ *e-mail: roswitalt@uny.ac.id
}

\begin{abstract}
The use of blended learning in foreign language instruction such as French has been widely practiced by teachers in many countries, including Indonesia. As French for Indonesian is somehow not an easy subject to learn, the blended learning has not been widely implemented. In this regard, the aim of this study was to investigate whether there could be an improvement in the quality of learning when blended learning in French Intermediate Grammar courses for Indonesian was applied. An embedded mixed method design consisting of quantitative and qualitative approaches was used to analyse the collected data in this research, where the main method was quasi-experiment using the pretest-posttest design. This study was conducted in one semester in seven synchronization activities. Data were collected by tests, questionnaires and observation sheets from 37 students taking French intermediate grammar course as the research respondents. The tests were reliable (Alpha Cronbach $=.925$ ). Moreover, the results showed that there were significant improvements among students, thus suggesting that blended learning can maximize the quality of learning (sig. <.05). The qualitative data informs that students were more independent in developing their creativity, autonomy and innovation in managing blended learning, hence the learning outcome was achieved.
\end{abstract}

\section{Keywords: blanded learning, innovative, competency, French grammaire, perception}

\section{BLENDED LEARNING DALAM PEMBELAJARAN GRAMMAIRE INTERMEDIARE DU FRANÇAIS: APAKAH EFEKTIF?}

\begin{abstract}
Abstrak: Penggunaan blended learning dalam pengajaran bahasa asing, seperti bahasa Perancis telah banyak dipraktikkan oleh para guru di banyak negara termasuk Indonesia. Karena bahasa Prancis untuk bahasa Indonesia bukanlah pelajaran yang mudah dipelajari, bagaimanapun, blended learning belum diterapkan secara luas. Tujuan penelitian ini adalah untuk menjelaskan peningkatan kualitas pembelajaran Grammaire Intermediare du Français dengan menggunakan blended learning bagi mahasiswa berbahasa Indonesia. Metode campuran kuantitatif dan kualitatif digunakan untuk menganalisis data dalam penelitian ini. Metode utamanya adalah quasi-exsperiment dengan menggunakan desain pretes-postes. 37 mahasiswa yang mengikuti mata kuliah Grammaire Intermediare du Français terlibat sebagai responden penelitian. Penelitian ini dilakukan selama satu semester dalam tujuh kegiatan asinkronisasi. Pengumpulan data dilaksanakan menggunakan tes, kuesioner, dan lembar observasi. Reabilitas tes dilakukan dengan Alpha Cronbach $(0,925)$. Hasil penelitian menunjukkan bahwa blended learning sangat baik dalam memaksimalkan kualitas pembelajaran karena terdapat peningkatan yang signifikan $($ sig. $<0,05)$. Data kualitatif menunjukkan bahwa mahasiswa lebih mandiri dalam mengembangkan kreativitas dan inovasi dalam pembelajaran dengan blended learning, dengan demikian hasil pembelajaran tercapai dengan baik.
\end{abstract}

Kata Kunci: blanded learning, inovasi, kompetensi, gramatikal bahasa Prancis, persepsi

\section{INTRODUCTION}

Using the technology in education has become necessary. Nowadays a lot of high educational institutions use such technology. Through this technology, student gets the opportunity to learn in a group (classroom) with a lecturer and additionally out side of class at a convenient time. Students can set the optimal speed and intensity of the learning process, so that student can discipline themself to learn and o work independently (Suo \& Mei, 2018). Presidential Regulation No. 2/2015 relating to the National Medium Term Development Plan (2015-2019) explains that technological 
implementation is expected to contribute significantly to the national economy (Ministry of Research and Technology, 2107). This is certainly a challenge for students to continue to develop themselves so that they can master technology in the era of industrial revolution 4.0. In line with this, universities must prepare their graduates to have technological capabi lities. The study about the implementation of the blended learning is also very less done in Indonesia (Zainuddin \& Keumala, 2018). There are still many universities that have not optimized blended learning in providing lecture material. Although those universities already have adequate internet networks and they have been equipped with computer laboratories. For that reason, it is very important for lecturers at universities to realize that it is very important to improve the competitiveness of the Indonesian people in mastering information technology.

One of the efforts to improve the quality of learning is blended learning. Blended learning is an innovative teaching method, which combines different methods of learning supported by flexible interactive platforms and resources that offer new approaches to improving skills and upgrading competencies. Blended learning can be a combination of different methods of learning, different learning environments, different learning styles (Watson, 2008; Marsh, 2012). The component of this learning is presented in Figure 1. The blended learning model is not only the use of the internet to look for references in doing assignments given by the lecturer or to help enrich the understanding gained during classroom learning. This learning model is also a technology-rich instruction (Staker \& Horn, 2012). In line with Staker \& Horn (2012) research results about blended learning in English Language Teaching found that "Providing mixed learning courses with technical and pedagogical support is very important in language teaching.

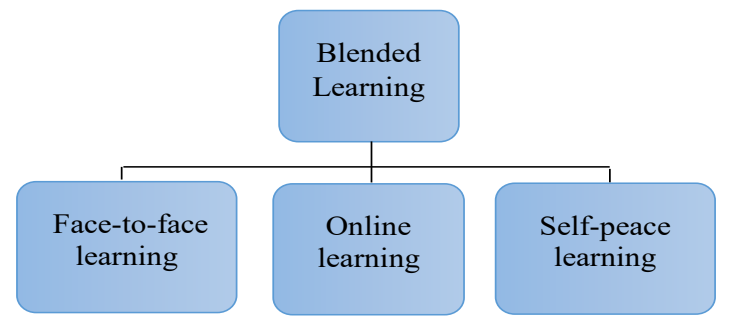

Figure 1. Components of Blended Learning
The elaboration of new competences in the framework of blended learning makes a great contribution into the development of students' skills. The acknowledged advantage of blended learning education is that the participants of the educational process are in constant contact with the teacher as in face-to-face format and in online environment.

The result of research about student' perceptions of the online lesson as compared with face-to-face lessons using Questionnaires with qualitative (Likert scale questions) and quantitative (open-ended questions) by Wright (2017) concluded that students preferred the online lesson. Convenience of study and flexibility of time and place of study as reasons for their choice. Skilful implementation of online lessons can enhance a language course but should not undermine the value of faceto-face instruction with EFL teachers. In line with Wright's opinion above, in her article entitled "Teaching Literature based on blended learning", Prawoto \& Pramulia (2019) explained that students could use blended learning as an online discussion without face-to-face activities. Students can correct each other, and give advice to friends in their groups. Blended learning can also be used as a medium for implementing technology. By using blended learning, students can transform literary works into other forms by utilizing applications: video makers or auto play. The findings research of = Mutaqin, Marethi, \& Syamsuri (2016) showed that the learning achievement of the students using blended learning was better than those using the conventional method. In addition, the students using blended learning were more active in doing the assignment than those in the conventional class.

By using blended learning, students always use the internet to find references in doing assignments given by lecturers and help them enrich the understanding gained during class learning (Watson, 2008). In teaching and learning using blended learning model, there are six elements that must exist, namely: (1) face to face, (2) independent learning, (3) application, (4) tutorials, (5) collaboration, and (6) evaluation. For that reason, in blended learning, researcher can use 5 models, namely: 1) Face-to-face driver model: face-to-face is done in classes outside the classroom by integrating web technology online; 
2) Rotation model: lecturers integrate online and face-to-face learning in class; 3) Flex model: utilizing internet media in learning deliverers. In this activity there are discussion groups in a forum; 4) Self-blend model: online self-learning, (not in the classroom); 5) Online driver model: lecturers upload learning material on the internet, students can download/ download it and learn independently outside the classroom (Tucker, 2012; Saliba, Rankine, \& Cortez, 2013; Sutisna, 2016).

Based on some experts'opinions and the results of the research above, it can be said that in learning with the blended learning model by preparing activities, material, activities in the form of collaboration, independent work and face-to-face presentations are very effective in improving the students' quality in learning foreign language. Blended learning' model can increase effectiveness and motivate students to learn independently by using additional material via the internet and they can use it in discussions either face-to-face in class or in e-learning forums.

In this paper, the recearcher will explain the quality of students in French Intermediate Grammar courses using blended learning. Blanded learning can be used in appropriate fields of foreign language knowledge, such as in grammatical learning. grammatical french for students is more difficult when it is compared with the english gammatical. Students in Indonesia had studied English when they were in Junior High School and Senior High School but most students do not have a basic knowledge of french grammatical. They learned french when they were in college. Blended learning, is one model of learning in the era of technology industry 4.0. Blended learning model can be used by students to expand the french language materials they obtained from lecturers. By using technology (internet), students can find resources that support their understanding of french grammar materials. Thus, this study aimed to explore the improvement french as foreign language student's grammatical knowledge using blended learning.

\section{METHOD}

The embedded mixed method design was used in this research, where the main methods is quasi-experiment using pre-test - post-test design. This study was conducted on one semester in seven synchronization activities. The descriptive statistics was used to describe the students' perception about the implementation of blended learning on French Grammar Intermediate course. Scaling is the branch of measurement that involves the construction of an instrument that associates qualitative constructs with quantitative metric units. Scaling evolved out of efforts in psychology and education to measure "unmeasurable" constructs like authori tarianism and self esteem" (Trochim \& William, 2006).

The respondents in this research were all of the second years students of french education departement at a state university in Yogyakarta who were attending the French Intermediate Grammar courses. The number of participants were 37 students, male and female. They were from classroom ' $\mathrm{J}$ ' and ' $\mathrm{K}$ '. The students of classroom ' $\mathrm{J}$ ' was 17 and the students of classroom ' $\mathrm{K}$ ' was 20.

Data collection used were tests, questionaire, and observation. The test of french intermediate grammar was used to measure the mastery level of student about the material that has been studied based on the syllabus using blanded learning. There were pre-test given to the student before treatment and post-test given at the end of the semester (the final semester examination). Qualitative data were analyzed to describe the observations results of the students' sentences. To give an high readability. All of the data on this paper were presented in tables and figures of frequencies The focus of observations were the activeness of students in classroom and in forum discussion using blended learning, the cooperation in discussion and the self-confidence in expressing opinions.

The pre-test and post-test items were adopted from the ECHO 2 textbook, which was compiled based on the level of European Standard Language Competency (CECR) at A2 level. Since the questions were adopted from the book, it is assumed that the content of the items already valid. Thus the authors do not test the validity of the pre-test and post-test instruments. The form of pre-test questions is multiple choice questions and field tests. The test grid can be seen in Table 1. 
Table 1. Spesification Table of Test Instrument

\begin{tabular}{|c|c|c|c|}
\hline No. & Indicator & Subindicator & Type of Items \\
\hline 1. & Tensss & $\begin{array}{l}\text { a. Present tense } \\
\text { b. Past tense and past perfect tense } \\
\text { c. Futur tense }\end{array}$ & $\begin{array}{l}\text { Completion \& } \\
\text { multiple choise }\end{array}$ \\
\hline 2. & Object pronouns & $\begin{array}{ll}\text { a. } & \text { Direct } \\
\text { b. } & \text { Indirect }\end{array}$ & Q-A \\
\hline 3. & Possessive pronouns & Possesive pronouns & Completion \\
\hline 4. & Imperatve & Verb imperatif & Completion \\
\hline 5. & Question word & Question word & Completion \\
\hline 6. & Comparative & & Completion \\
\hline 7. & Demonstrative pronouns & & Multiple choise \\
\hline 8. & Mode & Subjonctif & Completion \\
\hline
\end{tabular}

To get the information about students' perception, recearcher used questionnaire. This instrument was used to reveal students perception about the use and content of blanded learning in french intermediate grammar course. The closed questionnaire with five oprions was analyzed using a Likert scale (Murray, 2013; Creswell, 2012). The answer to each instrument item that uses a Likert scale has gradations from very positive to very negative, in the form of: Very Good $=5$, Good $=4$, Fair $=3$, Less $=2$, and very Less $=1$. Score each alternative answer given by the respondent in each the statement. The instrument of student perception contains indicators measured using Likert's 1-5, as shown in Table 2.

Table 2. Spesification Table of Questionnaire

\begin{tabular}{ll}
\hline No. Indicator & Remark \\
\hline 1. & The appearance of the website \\
presented & $1-5$ \\
2. Clarity of material description \\
3. Links that can be used to open \\
material and exercises from othersites \\
4. The language used is easy to \\
understand \\
5. Quality of training \\
6. Availability of forum columns at each \\
meeting \\
7. Number of assignments online \\
8. Percentage of lectures in the form of \\
synchronization and asynchronization
\end{tabular}

The content validity of the questionnaire was conducted by expert judgment in the form of a focus group discustion, while the reliability test used Cronbach's alpha statistics with the help of SPPS ver 22 and the result was that the questionnaire was valid and reliable (.925).
The observations' data was student activity noted during the discussion, on faceto-face activities and forum activities in asynchronization. To support the results of students' perceptions in using blended learning, researchers conducted observations during faceto-face activities in classroom. This observation method is related to data analysis that has been objectively documented (Denzin \& Lincoln, 2008). This method is also an empirical methodology that can be observed collectively (Tellis, 1997).

Data analysis techniques: descriptive statistics and nonparametric statistics Wilcoxonn (paired samples). The analysis of scores test based on final semester tests used descriptive statistics. This statistics was used simply to describe data to make inferences from it. Data obtained from the field are described and presented in tabular form. (Mardapi, 2012). From there, researcher can conclude the students' strenght and weakness in French intermediate grammar competence. Qualitative data were analyzed to describe the observations results of the students' sentences. To give an high readability. All of the data on this paper were presented in table.

\section{FINDINGS AND DISCUSSION Findings}

Findings of this study were divided into three. First is the average grade pretest and posttest of students. Second shows students'perceptions, to find more understanding of students' responses in teaching and learning using blended learning. Third is the results of observations that were used to support the results of test scores and students' responses using blended learning in learning French Intermediate Grammar. 
Students' Pre-tests and Post-test Score

The results of the of French Intermediate Grammar courses can be seen on Table 3 .

Table 3. Pre-test and Post-test Scores of French Intermediate Grammar

\begin{tabular}{lll}
\hline & Pre-test & Post-test \\
\hline$N$ & 37 & 37 \\
Mean & 65.95 & 76.16 \\
Median & 66.00 & 75.00 \\
Mode & 70 & 70 \\
Std. Deviation & 4.196 & 5.895 \\
Minimum & 50 & 61 \\
Maximum & 73 & 84 \\
\hline
\end{tabular}

Paired-sample $t$-test requires normal and homogeneous data. The results of the normality test data with Kolmogorov-Smirnov, it is known that the posttest score is not normal (sig. .00 < $.05)$, as shown in Table 4.

Table 4. Tests of Normality

\begin{tabular}{lcccccc}
\hline & \multicolumn{2}{c}{$\begin{array}{c}\text { Kolmogorov- } \\
\text { Smirnova }\end{array}$} & \multicolumn{3}{c}{ Shapiro-Wilk } \\
\cline { 2 - 7 } & Statistic & $\boldsymbol{d} \boldsymbol{f}$ & Sig. & Statistic & $\boldsymbol{d} \boldsymbol{f}$ & Sig. \\
\hline Pre-test & .146 & 37 & .044 & .881 & 37 & .001 \\
Post-test & .229 & 37 & .000 & .880 & 37 & .001 \\
\hline
\end{tabular}

Furthermore, to answer the question whether the use of blended learning can improve students' grammatical mastery, a difference test between the pre-test and post-test scores is done with the help of SPSS22. Because the sample distribution is not normal, the difference test was done by nonparametric statistical paired samples, the Wilcoxon test. From the calculation of the different test statistics it was found that there was a significant difference between the pre-test score and the post-test score as shown in Table 5.

Table 5. Test Results of Pre-test and post-test Difference

\begin{tabular}{lc}
\hline & Post-test - Pre-test Scores \\
\hline$Z$ & 3.314 \\
Asymp. Sig. (2-tailed) & .000 \\
\hline
\end{tabular}

\section{Students'Perceptions}

As mention before, students perception about the use and content of blanded learning in french grammar intermediate courses is conducted to to find more of students' responses in teaching and learning using blended learning. The results of research about the opinions of students in using blended learning in French intermediate grammar learning can be seen in Table 6.

From the results in the Table 6 , it can be explaned that more than $93 \%$ students who follow French Intermediate Grammar courses are interested in learning with blended learning, $(77.1 \%=$ Very Good and $16.9 \%=$ Good $)$.

Table 6. Students' Prceptions about the Use of Blended Learning

\begin{tabular}{|c|c|c|c|c|c|c|c|}
\hline \multirow{2}{*}{\multicolumn{2}{|c|}{ No. Variables }} & \multicolumn{5}{|c|}{ Scale } & \multirow{2}{*}{$\underset{\%}{\text { Amount }}$} \\
\hline & & \begin{tabular}{|c|}
5 \\
Very Good
\end{tabular} & $\begin{array}{c}4 \\
\text { Good } \\
\end{array}$ & $\begin{array}{c}3 \\
\text { Fair }\end{array}$ & $\begin{array}{c}2 \\
\text { Less }\end{array}$ & $\frac{1}{\text { Very Less }}$ & \\
\hline 1. & $\begin{array}{l}\text { The appearance of the } \\
\text { website presented }\end{array}$ & $\begin{array}{c}25 \\
(67.6)\end{array}$ & $\begin{array}{c}12 \\
(32.4 \%)\end{array}$ & - & - & - & $100 \%$ \\
\hline 2. & $\begin{array}{l}\text { Clarity of material } \\
\text { description }\end{array}$ & $\begin{array}{c}28 \\
(75.7)\end{array}$ & $\begin{array}{c}9 \\
(24.3 \%)\end{array}$ & - & - & - & $100 \%$ \\
\hline 3 & $\begin{array}{l}\text { Links that can be used } \\
\text { to open material and } \\
\text { exercises from othersites }\end{array}$ & $\begin{array}{c}30 \\
(81.1 \%)\end{array}$ & $\begin{array}{c}7 \\
(18.9 \%)\end{array}$ & - & - & - & $100 \%$ \\
\hline 4 & $\begin{array}{l}\text { The language used is } \\
\text { easy to understand }\end{array}$ & $\begin{array}{c}24 \\
(64.9 \%)\end{array}$ & $\begin{array}{c}3 \\
(8.1 \%)\end{array}$ & $\begin{array}{c}10 \\
(27 \%)\end{array}$ & - & - & $100 \%$ \\
\hline 5 & Quality of training & $\begin{array}{c}30 \\
(81.1 \%)\end{array}$ & $\begin{array}{c}7 \\
(18.9 \%)\end{array}$ & & & & $100 \%$ \\
\hline 6 & $\begin{array}{l}\text { Availability of forum } \\
\text { columns at each meeting }\end{array}$ & $\begin{array}{c}37 \\
(100 \%)\end{array}$ & - & - & - & - & $100 \%$ \\
\hline 7 & $\begin{array}{l}\text { Number of online } \\
\text { assignments }\end{array}$ & $\begin{array}{c}24 \\
(64.9 \%)\end{array}$ & $\begin{array}{c}7 \\
(18.9 \%)\end{array}$ & $\begin{array}{c}5 \\
(13.5 \%)\end{array}$ & - & $\begin{array}{c}1 \\
(2.7 \%)\end{array}$ & $100 \%$ \\
\hline \multirow[t]{2}{*}{8} & $\begin{array}{l}\text { Percentage of lectures in } \\
\text { the form of synchroniza- }\end{array}$ & $\begin{array}{c}30 \\
(81.1 \%)\end{array}$ & $\begin{array}{c}5 \\
(13.5 \%)\end{array}$ & $\begin{array}{c}2 \\
(5.4 \%)\end{array}$ & - & - & $100 \%$ \\
\hline & & $\begin{array}{c}28.5 \\
(77.1 \%)\end{array}$ & $\begin{array}{c}6.25 \\
(16.9 \%)\end{array}$ & $\begin{array}{c}2.13 \\
(5.7 \%)\end{array}$ & $\begin{array}{l}.00 \\
(0 \%)\end{array}$ & $.13(.3 \%)$ & $37(100 \%)$ \\
\hline
\end{tabular}




\section{Observation}

Observation was carried out with the aim to see the learning process as a whole from the beginning to the end of the activity, by observing student learning activities in the classroom and in discussion forums through blended learning, it can be seen whether the learning outcomes and perceptions given by students through the questionnaire content are in accordance with the results of the observation.

Based on observations made by lecturers during face-to-face activities and forum activities in asynchronization, along with portfolios of independent assignments collected by students using online system, it can be said that students are very interested in blended learning. This was apparent during discussions in learning activities both face-to-face and online in forum activities. All students gave their opinions and some gave questions which were largely an extension of the material provided. Students also dare to use French in discussion activities, although not as a whole. They mixed Indonesian and French during the discussion. This happens because students are still in their second years. This was seen during discussions in learning activities both face-to-face and online in forum activities. All students give their opinions and some give questions which are mostly an extension of the material given.

\section{Discussion}

From the results of the above study it can be explained that the quality of French intermediate grammar learning with blended learning can work very well. The indication was the grammatical competence of respondents were satisfactory. The average grammar mastery score of 37 students who took French intermediate grammar courses was 76.16. Students masterd well French intermediate grammar material. The mean score of students posttest significantly increased. This means that all students can finish and master the material according to the syllabus, (97.30\%). Blended learning makes students master the course (material) because they can get more information (Ja'ashan, 2015). This is also supported by the results of research by Stricker, Weibel, \& Wissmath (2011) which show that the application of blended learning improves student performance.
From the results of a questionnaire about student perceptions, it can be seen that learning French Intermediate Grammar with blended learning is very helpful to students in improving their mastery of French Grammar. Akkoyunlu \& Soylu (2006) investigate the opinions of students about blended learning that more students participated in the online discussion forums, more they achieved. Students developed positive views towards blended learning. In the portfolio it appeared that almost all students done on all assignments given by the lecturer. This showed that students carry out their independent activities using the internet outside of online lecture hours and face to face, except if the student could not do the assignment until the specified time because he was sick. There were 3 students who could not upload assignments on time, 1 student did not work because of illness. the results of this study are also consistent with the results of research conducted by This is also reinforced by the research results of Won \& Yong (2016) about the level of student satisfaction with blended learning which explains that the satisfaction factor towards the use of blended learning has an important role in learning activities.

Additionally, blended learning can significantly enhance students' learning motivation and interest (Shih, 2013). The study came up with the conclusion that both the faceto-face lectures and the online tasks contributed to the learning process. This strongly supports the development of increasing students in French as foreign grammar knowledge, because in the activities of this forum, students can analyze matters relating to the expansion of french grammar that have been learned. Blended learning is seen as a method for establishing suitable educationnal environments for students to help them gain their objectives easily and enhance their learning through the use of appropriate technology. This is supported by the results of Isti'anah's research (2017) who discovered that blended learning is suitable to be applied in courses related to language skills, as well as in grammar. Given online activities help students practice their understanding of the material that has been acquired in the classroom. The order of presentation and regular assignments given online helped students practice their grammar skills. 
From the result above, students indicated that the display on the web has been very good, the description presented on the web were very clear. In addition to sharing files in power point form, by using blended learning, the lecturer also shared the links of videos in YouTube. Figure 2 is the example of videos that the lecturer share.

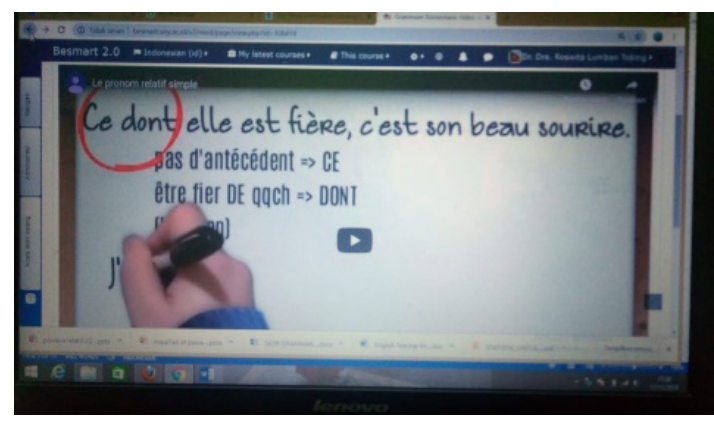

Figure 2. The Example of the Online Videos

Videos uploaded in blended learning activities based on the topic. Sharing this video aimed to attract students' attention and provided students an alternative learning resources. On blended learning activities, students watched the video many times. It made students understand very well, the subject related to intermediate grammar contained on the video. The language used by lecturers in the explanation of the material was very easy to understand. All students said that the availability of the forum column at each meeting was very motivating students to expand their knowledge about the lecture material that had been obtained.

In addition to the results of the questionnaire and the observations mentioned above. There was some inputs from students, about the time available for the collection of assignments, it was too short. Students need to open the internet to expand the material provided online, because there were other activities, namely participating in online forums. Students still attended on the other lectures and did the assignments given by the lecturer in each lecture which was attended by students. Inputs from those students can occur because of the time setting by students who have not been able to run well. Students who take French intermediate grammar were in their second year, so they still needed adjust to working independently and managing time in a guided manner.

Blended learning has a positive effect on student performance. as explained by Jee, $\mathrm{Ng}$, Lim, \& Lee (2016) that blended learning has a positive effect on student performance. This is shown from the increase in the average value of students at the time of the study in 2015, when compared with the previous year. the above opinion is also supported Lucia \& Stan (2018) who explained that online activities in learning can help increase student motivation. the use of media technology in the 21st century is nessesaire for lecturer to encourage their students in solving problems creatively, independently and creatively (Zainuddin \& Keumala, 2018). The key is that e-learning can function effectively for students in motivating and developing their language skills. technology is developing rapidly. perspectives on online learning change learners' motivation that second language learning relies not only on face-to-face interaction, but also on permanent feedback that can be provided by virtual platforms.

There are three important findings on how to improve Students' french intermediate grammar by using blended learning that can be used as a consideration in motivating students and teachers in learning French-language skills. First, students become accustomed to and very proficient in using the internet in the 4.0 era and they can complete their assignments independently outside the classroom with the blanded learning model. the use of the internet is very helpful for students to explore the material obtained on campus. By expanding French language knowledge through internet sites students are greatly helped in doing their independent assignments. Practicing grammar online regularly is proven to improve the students understanding of the materials. The use of language learning strategies has a positive correlation with their language acquisition (Suharsono, 2015). The exposure given helped students to recall the materials and exercise their grammar skills. Thus, it can create a new culture in learning second language (Isti'anah, 2017).

Secondly, students did not have to be in a certain class or room. All students are already have their laptop or mobile phone that can be used to download the material, upload their tasks and do the quiss given by the lecturer. students can also do their assignments outside the campus, according to the time specified by 
lecturer. Thirdly, with an attractive appearance on the material presented by the teacher, made students interested to read it. This will affect the interest students in reading that are expected to improve their ability to analyze the material. Fourth, Students can immediately see the score of the quiz as the result they are working at online system. This motivated students very much to master the lecture material, in order to obtain maximum grades.

\section{CONCLUSION}

This study aimed to investigate the effectivity of blended learning in French Intermediate Grammar courses. The finding of the results and discussion showed that blended learning was able to maximize the quality of students learning french intermediate grammar, since there were significant improvement (sig. .00< 00 ). Furthermore, more than $93 \%$ students who follow French Intermediate Grammar courses are interested in learning with blended learning, By using blended learning, students were more independent in developing their creativity, autonomy and innovation in managing blended learning. In line with this, it can be concluded that blended learning has a positive effect on student performance. These results are supported by Hsu \& Lin (2007), which stated that learners can interact, share and exchange knowledge with each other by virtual community. Based on the explanation above, it can be concluded that the learning of French Intermediate Grammar is effective and the outcome was achieved.

With the positive results of this research, a model of Blended Learning in more subjects in teaching foreign language as a secod language, expecially in French skills at the university in Indonesia can be implemented. From this result, it can be emphasized that learning activity should not only occur in the classroom but it can also go on outside the class through online media as Zaaenuddin \& Keumala (2018) explained in their research about blended learning method within Indonesian Higher Education Institutions.

Lecturers should prepare well the material that will be presented by using blended learning. The preparation of the material was not discussed in detail on this paper. It needs to be explained further in other studies.

\section{REFERENCES}

Akkoyunlu, B., \& Soylu, M. Y. (2006). A study on students' views on blended learning environment. Turkish Online Journal of Distance Education, 7(3), 43-56.

Creswell, J. (2012). Educational research: Planning, conducting and evaluating quantitative and qualitative research $\left(3^{\text {rd }}\right.$ ed). Upper Saddle Reiver, NJ: Pearson Education Inc.

Denzin, N. K. \& Lincoln, Y. S. (2008). Collecting and interpreting qualitative materials $\left(3^{\text {rd }}\right.$ ed). Thousand Oaks, CA: Sage Publications.

Hsu, C. L., \& Lin, J. C. C. (2007). Acceptance of blog usage: The roles of technology acceptance, social influence and knowledge sharing motivation. Information \& Management, 45(1), 65-74. https://doi.org/10.1016/j.im.2007.11.001.

Isti'anah, A. (2017). The effect of blended learning to the students' achievement in grammar class. IJEE (Indonesian Journal of English Education), 4(1), 16-30. https://doi.org/10. 15408/ijee.v4i1.5697.

Ja'ashan, M. M. N. H. (2015). Perceptions and attitudes towards blended learning for english courses: A case study of students at University of Bisha. English Language Teaching, 8(9), 40-50. https://doi. org/10.5539/elt.v8n9p40.

Jee, K. S., Ng, P. K., Lim, S. T., \& Lee, C. H. (2016). The effectiveness of blended learning: A case study undergraduate engineering students in a Private University. Australian Journal of Basic and Applied Sciences, 10(3), 46-51. www. ajbasweb.com.

Lucia, M. G. R., \& Stan, V. M. (2018). Second language acquisition via virtual learning platforms: A case study on Romanian experiences. Journal on Interdisciplinary Studies in Humanities, 10(3), 180190. https://doi.org/10.21659/rupkatha. v10n3.15.

Mardapi, D. (2012). Pengukuran penilaian 
\& evaluasi pendidikan. [Assessment measurements \& educational evaluation]. Yogyakarta: Nuha Litera.

Marsh, D. (2012). Blended learning: Creating learning opportunities for language learners. New York, NY: Cambridge University Press.

Ministry of Research and Technology. (2017). Panduan teknis indikator kinerja pengembangan pusat unggulan Iptek Tahun 2017. [Technical guide for performance indicators for the development of the leading Iptek Center in 2017]. Jakarta, Indonesia: Direktorat Jenderal Kelembagaan Iptek dan Dikti.

Murray, J. (2013). Likert data: What to use, parametric or non parametric. International Journal of Business and Social Science, 4(11), 259-264. www. ijbssnet.com.

Mutaqin, A., Marethi, I., \& Syamsuri, S. (2016). Model blended learning di Program Studi Pendidikan Matematika Untirta. Cakrawala Pendidikan, 35(1), 134-141. https://doi.org/10.21831/cp.v1i1.8384.

Prawoto, E. C., \& Pramulia, P. (2019). Pembelajaran sastra berbasis blended learning. [Literary learning based on blended learning]. Online Journal Efektor, 6(1), 37-42. https://doi.org/10.29407/e. v6il. 12532.

Saliba, G., Rankine, L., \& Cortez, H. (2013). Fundamentals of blended learning. Sydney: University of Western Sydney.

Shih, R. C. (2013). Effect of using facebook to assist english for business communication course instruction. The Turkish Online Journal of Educational Technology, 12(1), 52-59. https://www.learntechlib. org $/ \mathrm{p} / 132122 /$.

Staker, H., \& Horn, M. B. (2012). Classifying K-12 blended learning. Mountain View, CA: Innosight Institute.

Stricker, D., Weibel, D., \& Wissmath, B. (2011). Efficient learning using a virtual learning environment in a university class. Computers \& Education, 56(2), 495-50. https://doi.org/10.1016/j. compedu.2010.09.012.

Suharsono, S. (2015). Pemerolehan klausa relatif pada Pemelajar Bahasa Indonesia bagi Penutur Asing (BIPA): Kajian BahasaAntara. [The acquisition of relative clauses by BIPA learners: An interlanguage study]. Jurnal Litera, 14(1), 57-74. https://doi. org/10.21831/1tr.v14i1.4407.

Suo, S. Y., \& Mei, S. Y. (2018). Perceptions and practices of blended learning in foreign language teaching at USIM. European Journal of Social Sciences Education and Research, 12(1), 170-176. https://doi. org/10.26417/ejser. v12i1.

Sutisna, A. (2016). Pengembangan model pembelajaran blended learning pada pendidikan kesetaraan program Paket $\mathrm{C}$ dalam meningkatkan kemandirian belajar. [Development of blended learning model on equality education of the package $\mathrm{C}$ program in improving learning independence]. Jurnal Teknologi Pendidikan, 18(3), 156-168. https://doi. org/10.21009/JTP 1803.2.

Tellis, W. M. (1997). Application of a case study methodologi. Journal of The Qualitative Report, 3(3), 1-19. http://www.nova.edu/ ssss/QR/QR3-3/tellis2.html.

Trochim, W. M. K., \& Donnely, J. P. (2006). Research methods knowledge base (3 ${ }^{\text {rd }}$ ed). Mason, Ohio, United States: Atomic Dog.

Tucker, C. R. (2012). Blended learning grade 4-12. Thousand Oaks, CA: Corwin A Sage Company.

Watson, J. (2008). Blended learning: Convergence between online and face to face education. USA: North American Council for Online Learning. https://files. eric.ed.gov.

Won, S. C., \& Yong, T. Y. A. ( 2016). An empirical evaluation of critical factors influencing learner satisfaction in 
blended learning: A pilot study. Universal Journal of Educational Research, 4(7), 1667-1671. https://doi.org/10.13189/ ujer.2016.040719.

Wright, B. M. (2017). Blended learning: Student perception of face-to-face and online EFL lessons. Indonesian Journal of Applied
Linguistics, 7(1), 64-71. https://doi. org/10.17509/ ijal.v7i1.685.

Zainuddin, Z., \& Keumala, C. M. (2018). Blended learning method within indonesian higher education institutions. Jurnal Pendidikan Humaniora, 6(2), 69-77. http://journal. um.ac.id/index.php/jph. 